\title{
PERANCANGAN ENTERPRISE ARCHITECTURE PADA FUNGSI PENGEMBANGAN KARIER MENGGUNAKAN TOGAF ADM (STUDI KASUS UNIVERSITAS TELKOM)
}

\section{ENTERPRISE ARCHITECTURE DESIGN ON CAREER DEVELOPMENT FUNCTIONS USING TOGAF ADM (CASE STUDY: TELKOM UNIVERSITY)}

\author{
${ }^{1}$ Gita Desca Purnama, ${ }^{2}$ Yuli Adam Prasetyo, ${ }^{3}$ Rahmat Mulyana \\ 1,2,3Program Studi Sistem Informasi, Fakultas Rekayasa Industri, Universitas Telkom \\ 19itadesca16@gmail.com, ${ }^{2}$ adam@telkomuniversity.ac.id, ${ }^{3}$ rahmat.moelyana@gmail.com
}

\begin{abstract}
Abstrak - Jumlah lulusan Tel-U sampai saat ini telah mencapai 25.856 orang sejak tahun 1990. Untuk memenuhi kebutuhan mahasiswa tingkat akhir dan lulusan, Tel-U didukung oleh Direktorat Pusat Pengembangan Karir. Tetapi peran teknologi informasi untuk mendukung kegiatan yang berada pada Direktorat Pusat Pengembangan Karier belum dilakukan secara maksimal. Oleh karena itu dalam penelitian ini akan membahas mengenai perancangan Enterprise Architecture yang sesuai pada fungsi bisnis pengembangan karier Tel-U. Dalam perancangan enterprise architecture ini menggunakan TOGAF ADM. Langkah-langkah dalam TOGAF ADM dilakukan pada penelitian ini akan meliputi fase Preliminary, Architecture Vision, Business Architecture, Data Architecture, Technology Architecture, Opportunities and Solutions dan Migration Planning. Hasil dari perancangan Enterprise Architecture ini berupa blueprint enterprise architecture dan rekomendasi pengembangan TI dalam bentuk IT Roadmap. Dari hasil perancangan yang telah dibuat diharapkan dapat menjadi pedoman dalam pengembangan teknologi informasi pada Universitas Telkom khususnya pada fungsi pengembangan karier.
\end{abstract}

Kata kunci: Enterprise Architecture, Pengembangan Karier, Perguruan Tinggi, TOGAF ADM

\begin{abstract}
The number of Tel-U graduates to date has reached 25,856 people since 1990. To meet the needs of graduate and graduate students, Tel-U is supported by the Directorate of Career Development Center. The role of information technology to support activities that are at the Directorate of Career Development Center has not been done optimally. Therefore, in this research will discuss the design of Enterprise Architecture that fit on the business function of Tel-U career development. The design of this enterprise architecture using TOGAF ADM. The steps in TOGAF ADM carried out in this research will include the Preliminary phase, Architecture Vision, Business Architecture, Data Architecture, Technology Architecture,
\end{abstract}

\begin{tabular}{ll}
\hline Sejarah artikel & \\
Diterima redaksi: & $:$ 24 Juni 2017 \\
Revisi akhir & $:$ 24 Juli 2017 \\
Diterbitkan online & $:$ 22 Desember 2017
\end{tabular}

Opportunities and Solutions and Migration Planning. The result of Enterprise Architecture design is blueprint enterprise architecture and IT development recommendation in the form of IT Roadmap. From the results of the design that has been made is expected to be a guide in the development of information technology at Telkom University, especially in the career development function.

Keywords: Enterprise Architecture, Career Development, Higher Education, TOGAF ADM

\section{PENDAHULUAN}

Teknologi informasi (TI) yang berkembang dengan pesat saat ini merupakan hal yang dapat menunjang dan memudahkan sebuah organisasi dalam mengambil keputusan, menjalankan aktivitas bisnis dan pengelolaan informasi. Dengan adanya dukungan dari teknologi informasi maka dapat membantu dalam memberikan solusi bisnis [1]. Masalah yang biasa muncul dalam organisasi adalah pemanfaatan teknologi informasi yang kurang mendukung aktivitas bisnis organisasi. Sehingga teknologi informasi yang sudah ada menjadi sia-sia dan tidak mendukung produktivitas organisasi. Oleh karena itu, sebelum melakukan implementasi teknologi informasi dalam organisasi sebaiknya terlebih dahulu dibuat perancangan dan pemodelan yang dapat digunakan pada semua aspek yang terkait agar dapat mendukung kebutuhan organisasi.

Universitas Telkom, yang selanjutnya dapat disebut Tel-U merupakan penggabungan dari beberapa institusi yang berada di bawah badan penyelenggara Yayasan Pendidikan Telkom (YPT). Tel-U merupakan perguruan tinggi swasta yang terkenal dengan teknologi informasinya. Hal tersebut dapat dilihat dengan adanya peran Direktorat Sistem Informasi (SISFO) yang mendukung perkembangan teknologi informasi di Tel-U. Direktorat SISFO berfungsi sebagai sebuah unit yang mengelola dan menerapkan TIK untuk seluruh unit yang ada di Tel-U [2]. Direktorat SISFO telah mengembangkan aplikasi utama yang mendukung proses bisnis pada masing-masing fungsi bisnis Tel-U, aplikasi yang dimaksud bernama 
iGracias. iGracias sudah digunakan oleh hampir seluruh unit, selain itu iGracias juga dapat digunakan oleh mahasiswa, alumni dan dosen. Tetapi, masih terdapat beberapa kekurangan dari aplikasi iGracias, yakni apabila banyak mahasiswa yang mengakses iGracias pada waktu tertentu secara bersamaan seperti pada waktu registrasi mata kuliah dan penerimaan mahasiswa baru mengakibatkan database menjadi overload dan iGracias sulit untuk diakses.

Tel-U mempunyai beberapa fungsi bisnis, salah satu fungsi bisnis yang menjadi fokus dari penelitian yakni fungsi pengembangan karier, fungsi ini berada di bawah Direktorat Pusat Pengembangan Karier atau yang selanjutnya dapat disebut Tel-U Career. Pemilihan fungsi ini didasarkan karena belum adanya perancangan enterprise architecture pada Tel-U Career. Tel-U Career berfokus untuk mengupayakan pemenuhan kebutuhan mahasiswa akhir dan lulusan untuk menjadi lulusan yang berkualitas dan memiliki kompetensi yang baik untuk bersaing bersama perguruan tinggi lain. Selain itu, Tel-U Career juga menjadi penghubung bagi lulusan dengan perusahaan [3]. Namun, saat ini masih terdapat kendala dalam segi alur perencanaan seluruh fungsi pada Tel-U Career, kendala yang dapat dilihat saat ini adalah belum adanya keterkaitan antara fungsi satu dengan yang lain sehingga fungsi pada Tel-U Career berdiri sendiri, hal tersebut disebabkan karena belum adanya suatu sistem atau aplikasi yang dapat menunjang seluruh fungsi agar dapat melakukan sharing data secara real time. Selain itu, masih terdapat beberapa kegiatan operasional pada fungsi pengembangan karier dikerjakan secara manual. Kendala lain mengenai perkembangan teknologi informasi yang juga dirasakan oleh Tel-U Career adalah pada website Tel-U Career belum terdapat fitur untuk login, sehingga masyarakat umum dapat mengakses semua data yang terdapat pada website tersebut, hal tersebut mengakibatkan data tidak terjamin keamanannya, selain itu website belum mendukung fitur apply lamaran pekerjaan bagi alumni dan masyarakat umum sehingga belum mendukung tujuan organisasi secara optimal. Mengacu pada pencarian data dengan menggunakan metode wawancara dan observasi yang telah dilakukan, maka hasil yang didapatkan telah dirangkum pada Tabel I.

TABLE I

PENGGUNAAN APLIKASI PADA FUNGSI PENGEMBANGAN KARIER

\begin{tabular}{cccc}
\multicolumn{2}{c}{ PENGGUNAAN APLIKASI PADA FUNGSI PENGEMBANGAN KARIER } \\
\cline { 2 - 3 } $\begin{array}{c}\text { Sub Fungsi pada } \\
\text { Tel-U } \text { Career }\end{array}$ & iGracias & $\begin{array}{c}\text { Website } \text { Tel- } \boldsymbol{U} \\
\text { Career }\end{array}$ & Status \\
\hline $\begin{array}{c}\text { Penyaluran Lulusan } \\
\text { dan Tracer }\end{array}$ & $\checkmark$ & & $\begin{array}{c}\text { Belum ada } \\
\text { integrasi antara } \\
\text { iGracias dengan } \\
\text { website Tel-U } \\
\text { Career }\end{array}$ \\
$\begin{array}{c}\text { Pengembangan } \\
\text { Karier }\end{array}$ & - & $\checkmark$ & Tercover Sebagian \\
\hline
\end{tabular}

Seperti yang telah disampaikan sebelumnya bahwa untuk menyelaraskan kebutuhan teknologi dengan bisnis pada fungsi bisnis pengembangan karier dibutuhkan sebuah perancangan dan pemodelan enterprise architecture, yang akan disebut EA. Menyadari bahwa Tel-U belum memiliki blueprint dalam mengembangkan sistem informasi, maka organisasi perlu membuat perancangan EA yang dapat meningkatkan keunggulan teknologi informasi dan membantu organisasi dalam pengelolaan teknologi informasi. Framework yang digunakan untuk melakukan perancangan Enterprise Architecture adalah TOGAF (The Open Group Architecture Framework), dengan komponen berupa TOGAF ADM (Architecture Development Method). Kelebihan menggunakan framework TOGAF ini adalah karena sifatnya yang fleksibel sehingga dapat dikombinasikan dengan framework lain seperti Zachman Framework ataupun FEAF dan pemodelan serta perancangan yang ada di dalamnya sudah lengkap untuk menggambarkan sistem informasi yang dapat mendukung kebutuhan sebuah organisasi [4]. Oleh karena itu, solusi yang dapat diberikan dari permasalahan-permasalahan yang telah dijelaskan sebelumnya adalah berupa perancangan enterprise architecture. Contoh dari solusi EA yang dapat dilakukan adalah pembuatan menu login pada website Tel-U Career, login dapat dibedakan berdasarkan peran dari setiap stakeholder yang berhubungan dengan penggunaan website tersebut, misalnya user website Tel-U Career dibedakan menjadi lulusan, pencari kerja atau masyarakat umum, dan perusahaan atau organisasi yang bekerja sama dengan Tel-U Career. Selain itu solusi yang dapat diberikan adalah memaksimalkan penggunaan teknologi informasi dalam hal pembangunan sistem atau aplikasi pada fungsi pengembangan karier Tel-U karena masih terdapat beberapa kegiatan operasional yang masih dilakukan secara manual.

\section{STUDILITERATUR}

Menurut Mark Lankhorst enterprise adalah sekumpulan organisasi yang memiliki beberapa tujuan/prinsip umum [5]. Menurut Electronic Industry Association architecture merupakan komponen-komponen sebuah sistem yang terdiri dari jaringan, perangkat keras dan lunak yang restruktur [6]. Sedangkan, Enterprise Architecture menurut Scott A. Bernard adalah suatu profesi dan praktek manajemen yang didedikasikan untuk meningkatkan kinerja suatu perusahaan dengan cara membuat perusahaan tersebut mampu secara keseluruhan, mengintegrasikan strategi praktek-praktek bisnisnya, alur-alur informasinya dan sumber daya teknologinya [7]. Dengan memahami pengertian enterprise architecture di atas, maka dapat dinyatakan enterprise architecture merupakan kumpulan prinsip, metode, dan model yang bersifat realistis yang dapat digunakan untuk mendesain dan merealisasikan sebuah struktur organisasi, proses bisnis, sistem informasi serta infrastrukturnya. Terdapat beberapa framework yang dapat digunakan untuk merancang enterprise architecture, yakni TOGAF, FEAF dan Zachman. Dalam melakukan perancangan enterprise architecture diperlukan framework arsitektur yang sesuai dengan penelitian ini. Untuk memilih sebuah EA framework terdapat kriteria yang berbeda yang dapat dijadikan sebagai acuan, antara lain: framework yang masuk akal yang dapat memungkinkan pembuatan arsitektur yang bersifat deterministic ketika terjadi perubahan dan tetap mejaga integritasnya walaupun menghadapi perubahan bisnis dan teknologi, framework harus kohesif memiliki sekumpulan perilaku yang akan seimbang dalam cara pandang dan scope-nya, framework harus dapat beradaptasi terhadap perubahan dan framework haruslah tidak tergantung pada vendor tertentu untuk benar-benar memaksimalkan benefit bagi organisasi. Dari kriteria tersebut dapat dilakukan perbandingan beberapa framework yang ditunjukan pada Tabel II [4]. Berdasarkan pemaparan Tabel II dapat dapat dengan jelas dibedakan karakteristik dari framework Zachman, FEAF dan TOGAF. Dengan melihat dari masing-masing 
framework, maka framework yang dipilih sebagai acuan pengembangan penelitian ini adalah TOGAF. Framework TOGAF dipilih karena sesuai dengan kebutuhan dibandingkan dengan metode-metode lainnya, selain itu TOGAF dinilai lengkap dari kriteria dan komponen penyusunannya. The Open Group Architecture Framework (TOGAF) adalah sebuah framework yang dikembangkan oleh The Open Group's Architecture Framework pada tahun 1995, pada tahun tersebut The Open Group memunculkan versi pertama dari TOGAF (versi 1.0) dan yang digunakan sampai saat ini adalah TOGAF 9.1 yang dirilis tahun 2011. TOGAF terdiri dari beberapa komponen, antara lain [8]:

a. Architecture Development Method (ADM)

b. ADM Guidelines and Techniques

c. Architecture Content Framework

d. TOGAF Reference Models

e. The Enterprise Continuum

f. The Architcture Capability Framework

TABLE II

PERBANDINGAN DENGANFRAMEWORK ENTERPRISE ARCHITECTURE

\begin{tabular}{|c|c|c|c|}
\hline & Zachman & FEAF & TOGAF \\
\hline $\begin{array}{l}\text { Definisi arsitektur } \\
\text { dan } \\
\text { pemahamannya }\end{array}$ & Parsial & Ya & $\begin{array}{l}\text { Ya Pada fase } \\
\text { preliminary }\end{array}$ \\
\hline $\begin{array}{c}\text { Proses Arsitektur } \\
\text { yang detil }\end{array}$ & $\mathrm{Ya}$ & Tidak & $\begin{array}{l}\text { Ya ADM dengan } \\
9 \text { fase yang detil }\end{array}$ \\
\hline $\begin{array}{l}\text { Support terhadap } \\
\text { evolusi arsitektur }\end{array}$ & Tidak & $\mathrm{Ya}$ & $\begin{array}{c}\text { Ya Ada fase } \\
\text { migration planning }\end{array}$ \\
\hline Standarisasi & Tidak & Tidak & $\begin{array}{l}\text { Ya Menyediakan } \\
\text { TRM, standards } \\
\text { information }\end{array}$ \\
\hline $\begin{array}{c}\text { Architecture } \\
\text { Knowledge Base }\end{array}$ & Tidak & Ya & Ya \\
\hline Pendorong bisnis & Parsial & Ya & Ya \\
\hline Input Teknologi & Tidak & $\mathrm{Ya}$ & Ya \\
\hline Model bisnis & $\mathrm{Ya}$ & $\mathrm{Ya}$ & $\mathrm{Ya}$ \\
\hline Desain transisional & Tidak & Ya & $\begin{array}{l}\text { Ya Hasil fase } \\
\text { migration planning }\end{array}$ \\
\hline Neutrality & $\mathrm{Ya}$ & Tidak & $\mathrm{Ya}$ \\
\hline $\begin{array}{l}\text { Menyediakan } \\
\text { prinsip arsitektur }\end{array}$ & Tidak & $\begin{array}{c}\text { Tidak Hanya } \\
\text { untuk } \\
\text { karakteristik } \\
\text { FEAF }\end{array}$ & Ya \\
\hline
\end{tabular}

Salah satu komponen dari TOGAF yang digunakan dalam perancangan enterprise architecture pada penelitian ini adalah Architecture Development Method (ADM). ADM merupakan metode untuk mengembangkan enterprise architecture yang terdiri dari delapan fase utama pengembangan pemeliharaan technical architecture dari perusahaan/organisasi. ADM merupakan metode yang fleksibel yang dapat mengidentifikasi berbagai macam teknik pemodelan yang digunakan dalam perancangan, karena metode ini bisa disesuaikan dengan perubahan dan kebutuhan selama perancangan dilakukan [9]. Terdapat beberapa fase dalam ADM yang membantu untuk merancang enterprise architecture, yaitu [10]:

a. Fase Preliminary

b. Architecture Vision

c. Business Architecture

d. Information System Architecture Technology Architecture e. Opportunities and Solutions

f. Migration Planning.

g. Implementation Governance

h. Architecture Change Management

i. Requirement Management

\section{METODOLOGI PENELITIAN}

Berdasarkan masalah dari penelitian ini, metode yang digunakan menggunakan model konseptual. Model konseptual merupakan gambaran umum pelaksanaan penelitian dalam merancang enterprise architecture pada fungsi pengembangan karier Universitas Telkom. Model konseptual diharapkan dapat memberikan gambaran dan mengarahkan asumsi mengenai variablevariabel yang diteliti. Pada penelitian ini terdapat tiga elemen yang menggambarkan alur penelitian dalam merancang enterprise architecture pada fungsi pengembangan karier. Ketiga elemen tersebut yaitu, permasalahan dan lingkungan.

Penelitian SI dan knowledge base yang dijelaskan sebagai berikut: Permasalahan yang diidentifikasi pada penelitian ini yaitu pendokumentasian SOP belum dilakukan pada seluruh proses bisnis, selain itu penggunaan aplikasi yang belum maksimal serta peran teknologi informasi belum dapat memenuhi kebutuhan bisnis pada fungsi pengembangan karier. Sedangkan lingkungan merupakan identifikasi terhadap organisasi yang terkait dengan penelitian ini. Elemen kedua berisi Penelitian SI, menggambarkan artefak artefak yang dibutuhkan untuk memberikan solusi pada permasalahan yang ada pada fungsi pengembangan karier Tel-U. Artefak yang digunakan dalam penelitian hanyalah core content yang terdiri dari matrices, catalog dan core diagram. Elemen knowledge base terdiri dari konsep dan metode. Konsep yang dapat diterapkan pada penelitian ini adalah perancangan enterprise architecture menggunakan framework TOGAF ADM. Metode adalah cara pengumuplan data yang dilakukan pada penelitian ini, antara lain wawancara, dan studi literatur observasi. Perancangan ini dilakukan pada sebuah perguruan tinggi swasta yaitu Universitas Telkom. Penlitian ini berupa perancangan enterprise architecture mengguankan TOGAF ADM, penelitian ini dilakukan dari fase preliminary sampai fase migration planning.

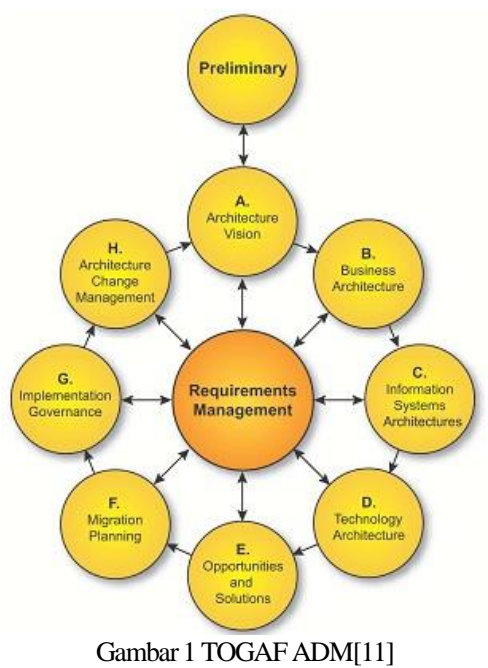




\section{HASIL DAN ANALISIS}

\section{A. Preliminary Phase}

Fase Preliminary merupakan tahapan pertama yang dilakukan dalam penyusunan arsitektur enterprise. Fase ini menjelaskan tentang persiapan apa saja yang dibutuhkan untuk memenuhi kebutuhan bisnis pembuatan arsitektur perusahaan. Pada tahap ini juga dilakukan identifikasi prinsip-prinsip arsitektur dari segi bisnis, data, aplikasi dan teknologi pada Universitas Telkom. Pada fase ini menghasilkan sebuah artefak yaitu principles catalog yang digunakan untuk memetakan prinsip-prinsip arsitektur yang dirancang. Principle catalog ditunjukan pada Tabel III.

TABLE III

PRINCIPLE CATALOG

\begin{tabular}{|c|c|c|c|}
\hline No. & $\begin{array}{l}\text { Kategori } \\
\text { Principle }\end{array}$ & Principle & Deskripsi \\
\hline \multirow{6}{*}{1} & \multirow{5}{*}{$\begin{array}{l}\text { Business } \\
\text { Principles }\end{array}$} & Memaksimalkan keuntungan bisnis & $\begin{array}{l}\text { Memaksimalkan manajemen bisnis untuk mendapatkan profit bagi Universitas Telkom dengan } \\
\text { memperluas area pemasaran dan menjalin kerja sama dengan instansi baik nasional maupun internasional }\end{array}$ \\
\hline & & $\begin{array}{l}\text { Manajemen informasi adalah tanggung } \\
\text { jawab semua bagian }\end{array}$ & $\begin{array}{c}\text { Setiap unit melakukan pegelolaan informasi yang dapat dipertanggungjawabkan dalam pelaksanaan } \\
\text { operasional bisnis }\end{array}$ \\
\hline & & Tanggung jawab teknologi informasi & $\begin{array}{c}\text { Pemanfaatan aplikasi dalam menjalankan operasional bisnis Universitas Telkom agar lebih efektif dan } \\
\text { efisien. }\end{array}$ \\
\hline & & Keberlangsungan bisnis & $\begin{array}{l}\text { Seluruh kegiatan operasional Universitas Telkom telah terdokumentasikan dengan adanya laporan kerja, } \\
\text { sehingga kegiatan tersebut tetap berjalan walaupun terdapat kendala pada sistem }\end{array}$ \\
\hline & & Kepatuhan terhadap hukum hukum & $\begin{array}{l}\text { Seluruh kegiatan manajemen bisnis Universitas Telkom sesuai dengan Keputusan Dewan Pengurus } \\
\text { Yayasan Pendidikan Telkom No. KEP.0318/00/SET-04/YPT/2014 mengenai Statuta Universitas Telkom }\end{array}$ \\
\hline & \multirow{6}{*}{$\begin{array}{l}\text { Data } \\
\text { Principles }\end{array}$} & Aset data & $\begin{array}{c}\text { Semua data yang digunakan untuk mendukung pelaksanaan operasional bisnis yang dapat terjamin } \\
\text { kerahasiaannya }\end{array}$ \\
\hline \multirow{5}{*}{2} & & Akses data & $\begin{array}{c}\text { Data dapat diakses oleh pihak yang berwenang terkait dalam pelaksanaan fungsi organisasi Telkom } \\
\text { University. }\end{array}$ \\
\hline & & Data valid & Setiap elemen data terjamin atas kualitas datanya \\
\hline & & Data realtime & Data dapat ter-update setiap saat \\
\hline & & Konsistensi data & $\begin{array}{c}\text { Data didefinisikan secara konsisten dan memiliki definisi yang mudah dipahami untuk semua pihak yang } \\
\text { terlibat dalam pelaksanaan fungsi organisasi. }\end{array}$ \\
\hline & & Keamanan data & Keamanan data diperlukan untuk melindungi data dari pihak luar Universitas Telkom \\
\hline \multirow{6}{*}{3} & \multirow{6}{*}{$\begin{array}{l}\text { Application } \\
\text { Principles }\end{array}$} & Fleksibilitas aplikasi & Aplikasi yang digunakan dapat beroperasi pada berbagai platform teknologi \\
\hline & & Kemudahan penggunaan & Aplikasi mudah digunakan oleh user dengan adanya manual book \\
\hline & & Integrasi aplikasi & $\begin{array}{c}\text { Aplikasi yang digunakan Universitas Telkom, meliputi akademik, non akademik, dan sistem informasi } \\
\text { pendukung saling terhubung. }\end{array}$ \\
\hline & & Support system & $\begin{array}{c}\text { Aplikasi dapat mendukung fungsi operasional bisnis, terutama untuk mendukung proses bisnis lowongan } \\
\text { pekerjaan }\end{array}$ \\
\hline & & Keamanan aplikasi & Keamanan aplikasi digunakan untuk melindungi hak paten aplikasi Universitas Telkom \\
\hline & & Hak akses aplikasi & Adanya pembatasan hak akses pada aplikasi \\
\hline \multirow{6}{*}{4} & \multirow{6}{*}{$\begin{array}{l}\text { Technology } \\
\text { Principles }\end{array}$} & Interoperability & $\begin{array}{c}\text { Penggunaan teknologi yang sesuai dengan industri menjamin keberlangsungan hidup sistem karena sudah } \\
\text { teruji kelayakannya dan sesuai dengan kebutuhan bisnis perusahaan }\end{array}$ \\
\hline & & Mendukung perubahan kebutuhan & Aplikasi dan teknologi yang dibuat dapat menanggapi perubahan kebutuhan bisnis. \\
\hline & & Backup infrastruktur teknologi & Adanya backup terhadap server jika suatu saat terjadi bencana \\
\hline & & Keamanan Teknologi & Keamanan teknologi harus selalu terjaga untuk pengelolaan server \\
\hline & & Penggunaan Teknologi secara Realtime & Penggunaan teknologi harus dapat menyesuaikan kapasitas penggunaan data \\
\hline & & Kontrol Teknik & Diperlukan untuk mengelola perubahan yang terjadi pada lingkungan teknologi \\
\hline
\end{tabular}

\section{B. Architecture Vision}

Fase Architecture Vision menjelaskan tentang tahap awal dalam Architecture Development Method (ADM). Tahapan dalam fase ini mengidentifikasi stakeholder yang terlibat dalam proses bisnis, mendefinikan visi arsitektur, mendefinisikan ruang lingkup, dan pada fase ini dilakukan penilaian kemampuan bisnis demi memenuhi kebutuhan organisasi. Pada Gambar 2 menunjukan value chain diagram.

\section{Fase Business Architecture}

Pada Business Architecture dilakukan pendeskripsian kondisi bisnis yang sedang berjalan saat ini. Tahap penting yang dilakukan pada tahap ini yaitu menggambarkan target. Untuk mengambarkan target, hal yang lebih dahulu dilakukan adalah mendeskripsikan service strategy, fungsional, proses yang ada pada organisasi dan organisasi dari lingkungan bisnis berdasarkan business principle, goals, dan driver. Pada Business Service/Function Catalog menjelaskan layanan-layanan yang terdapat dalam organisasi.
Katalog ini dibuat untuk mendefinisikan layanan-layanan bisnis berdasarkan fungsi bisnis yang ada pada organisasi. Business Service/Function Catalog ditunjukan pada Tabel IV.

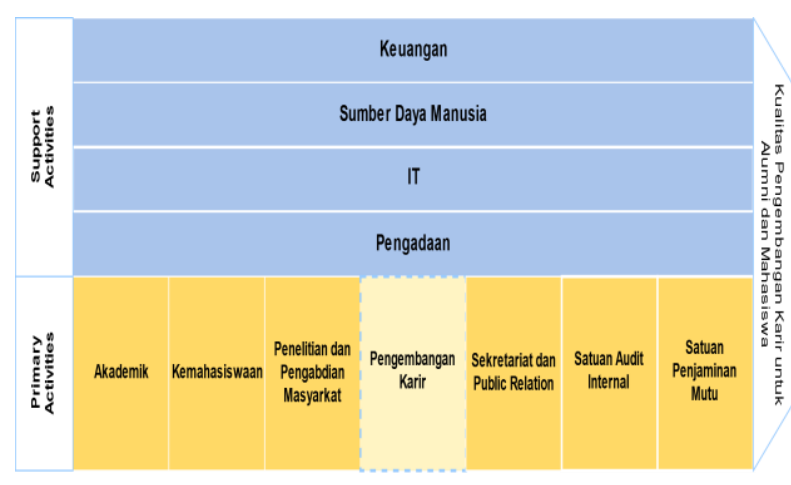

Gambar 2 Value Chain Diagram 
D. Fase Application Architecture

Application architecture merupakan bagian dari fase information system architecture dan merupakan tahapan ketiga pada TOGAF ADM. Pada fase ini menjelaskan application architecture apa saja yang dibutuhkan dalam pengembangan EA dan arsitektur yang mendukung business architecture dan data architecture yang telah dirancang sebelumnya. Fase application architecture bertujuan untuk menentukan jenis dari aplikasi yang dibutuhkan untuk memproses data serta dapat mendukung jalannya proses bisnis organisasi. Application Communication Diagram menggambarkan relasi antara komponen aplikasi fisikal dengan komponen aplikasi logikal. Artefak ini ditunjukan pada Gambar 4.
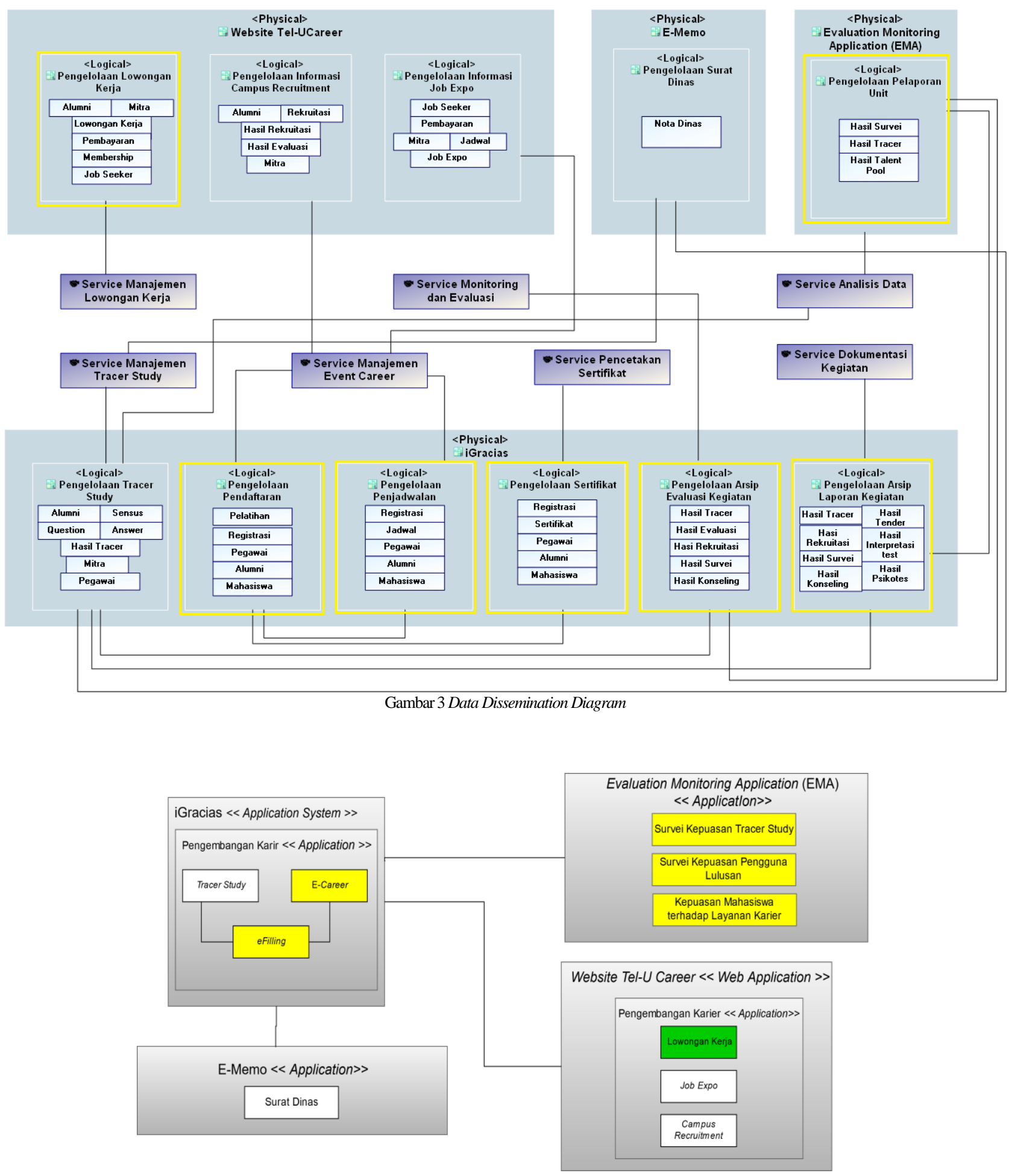

Gambar 4 Application Communication Diagram 


\section{E. Fase Technology Architecture}

Fase technology architecture berfungsi untuk membangun arsitektur teknologi yang dibutuhkan dalam perancangan dan pengembangan EA sehingga dapat memenuhi kebutuhan dari data dan application architecture yang telah didefinisikan sebelumnya. Salah satu artefak yang dihasilkan pada fase technology architecture yaitu platform decomposition diagram yang ditunjukan pada Gambar 5.

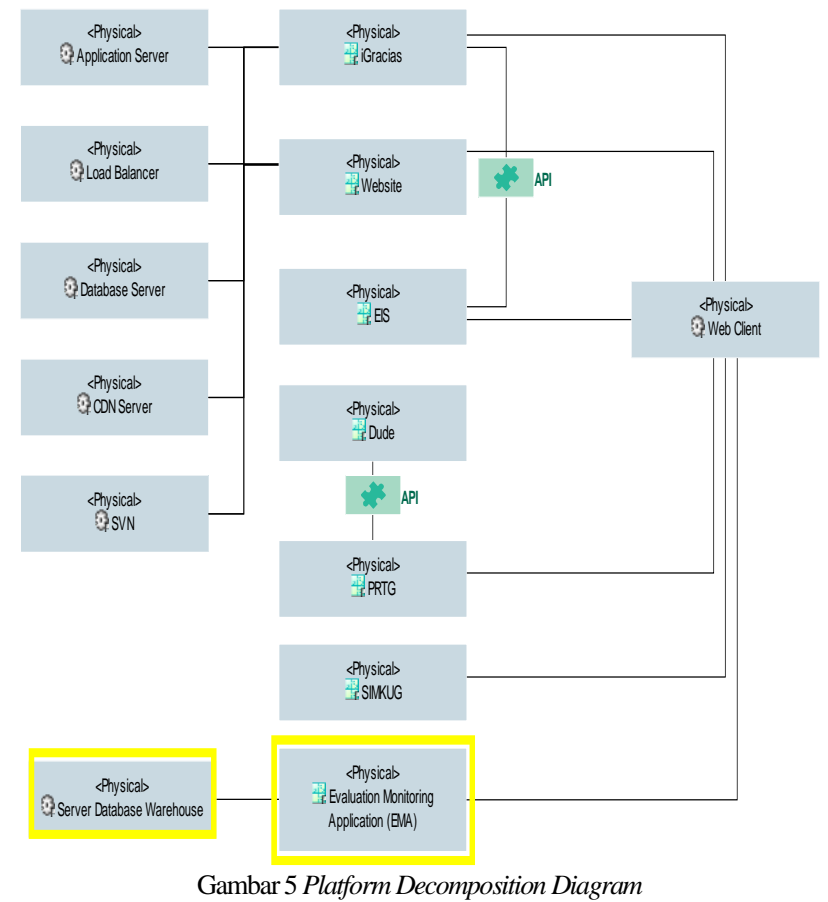

\section{F. Fase Opportunities and Solutions}

Pada tahap ini dilakukan evaluasi model yang telah dibangun untuk arsitektur saat ini dan tujuan, identifikasi proyek utama dilaksanakan untuk mengimplementasikan arsitektur tujuan dan klasifikasikan sebagai pengembangan baru atau penggunaan kembali sistem yang sudah ada. Project catalog ditunjukkan pada Tabel V.

\section{G. Fase Migration Planning}

Migration Planning merupakan proses migrasi dengan memastikan rencana pelaksanaan dan melakukan koordinasi migrasi dengan organisasi yang bertujuan untuk menerapkan perubahan portofolio organisasi secara keselurhan. Kegiatan yang dilakukan pada fase ini meliputi penilaian biaya, keterkaitan dan manfaat dari proyek dalam konteks aktivitas perusahaan.

Pada Gambar 6 menunjukan business value assessment. Berdasarkan gambar 6, dapat dilakukan analisis mengenai prioritas proyek yang akan dibangun terlebih dahulu. Prioritas diambil berdasarkan risk project TI dan penghitungan valuasi investasi proyek. Pada Tabel VI menunjukkan prioritas pembangunan proyek pada fungsi pengembangan karier Tel-U. Setelah mengurutkan proyek berdasarkan prioritas. Pada Gambar 7 dihasilkan IT Roadmap yang menjelaskan mengenai deskripsi pengembangan proyek yang dilakukan pada waktu tertentu. Pertimbangan durasi pelaksanaan proyek dilihat dari beberapa hal seperti resource, scope dan user requirement.

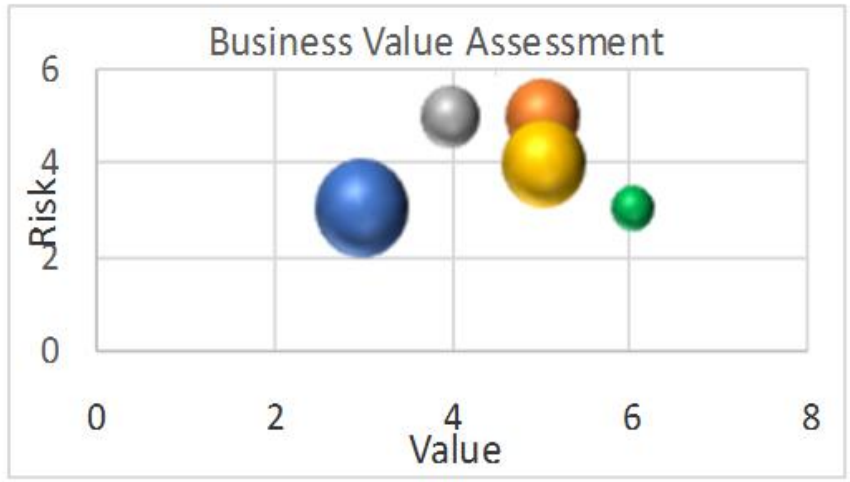

Gambar 6 Business Value Assessment

TABEL IV BUSINESS SERVICE/FUNCTIONCATALOG

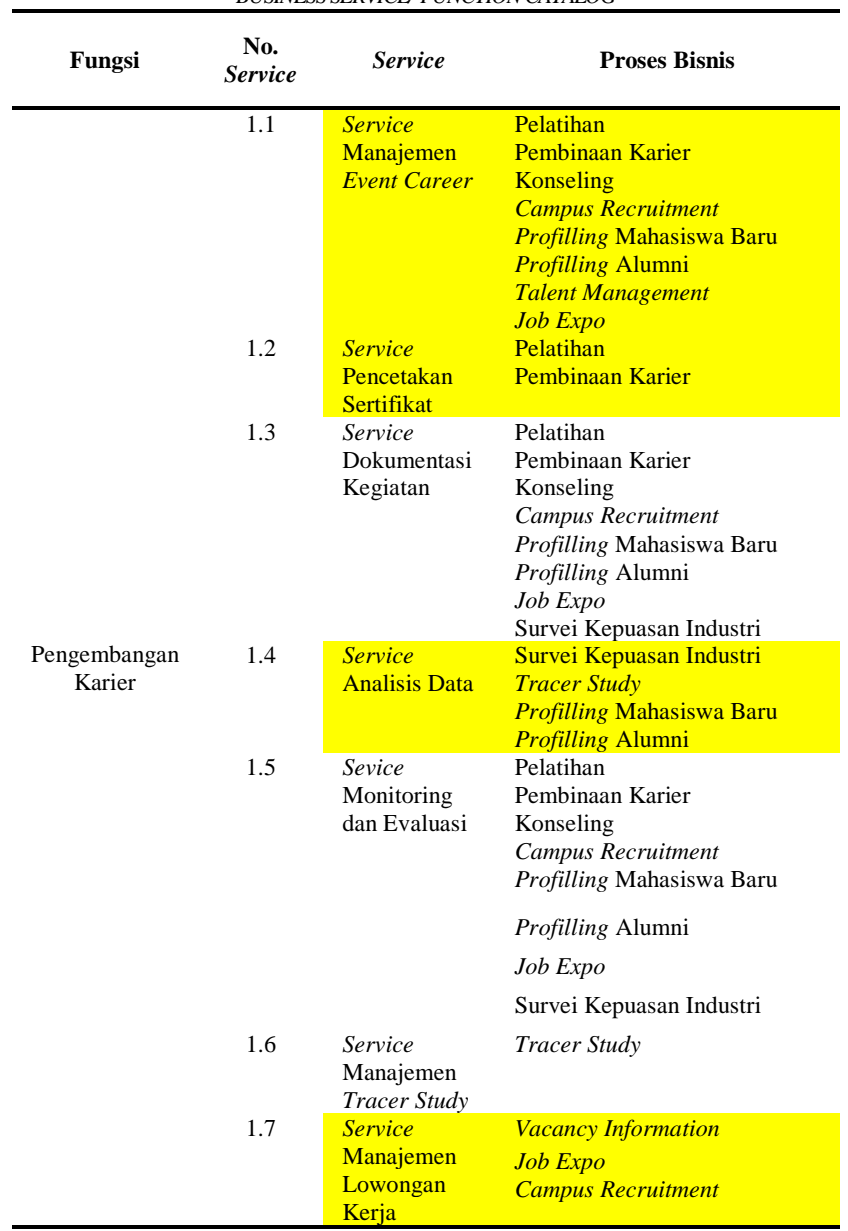

H. Evaluasi Penelitian

Hasil evaluasi digunakan untuk melihat dan mengetahui rekomendasi yang diusulkan sudah sesuai dengan kebutuhan bisnis, arsitektur, dan teknologi. Hasil evaluasi didapat melalui pemberian nilai persetujuan dan feedback/saran oleh stakeholder yang terlibat dalam perancangan arsitektur. Berdasarkan penelitian yang dilakukan evaluasi perancangan enterprise architecture ditunjukan pada Tabel VII. 
TABEL V

PROJECT CATALOG

\begin{tabular}{|c|c|c|c|c|}
\hline No & Project & Sub-Project & Service & Application \\
\hline 1 & $\begin{array}{l}\text { Pengembangan website Tel- } U \\
\text { Career }\end{array}$ & $\begin{array}{l}\text { Pendokumentasian } \\
\text { proses bisnis dengan } \\
\text { pembuatan SOP } \\
\text { Pembuatan fitur } \\
\text { lowongan pekerjaan } \\
\text { pada website Tel- } U \\
\text { Career }\end{array}$ & $\begin{array}{l}\text { Service Publikasi Lowongan } \\
\text { Kerja, Service Apply Lamaran } \\
\text { Kerja }\end{array}$ & Website Tel-U Career \\
\hline 2 & $\begin{array}{l}\text { Pembangunan aplikasi eFilling pada } \\
\text { iGracias }\end{array}$ & $\begin{array}{l}\text { Pendokumentasian } \\
\text { proses bisnis dengan } \\
\text { pembuatan SOP } \\
\text { Pembuatan aplikasi } \\
\text { eFilling } \\
\text { Integrasi aplikasi } \\
\text { eFilling dengan } \\
\text { iGracias }\end{array}$ & $\begin{array}{l}\text { Service pelaporan kegiatan, } \\
\text { Service monitoring dan evaluasi }\end{array}$ & eFilling \\
\hline 3 & $\begin{array}{l}\text { Pembangunan aplikasi E-Career } \\
\text { pada iGracias }\end{array}$ & $\begin{array}{l}\text { Pendokumentasian } \\
\text { proses bisnis dengan } \\
\text { pembuatan SOP } \\
\text { Pembuatan aplikasi E- } \\
\text { Career } \\
\text { Integrasi aplikasi E- } \\
\text { Career dengan } \\
\text { iGracias }\end{array}$ & $\begin{array}{l}\text { Service pendaftaran kegiatan, } \\
\text { service penjadwalan, service } \\
\text { pencetakan sertifikat }\end{array}$ & E-Career \\
\hline 4 & $\begin{array}{l}\text { Pengembangan infrastruktur } \\
\text { teknologi }\end{array}$ & $\begin{array}{l}\text { Penambahan } \\
\text { kapasistas RAM } \\
\text { Server }\end{array}$ & - & - \\
\hline 5 & $\begin{array}{l}\text { Pembuatan Data Warehouse dan } \\
\text { Evaluation Monitoring Application } \\
\text { (EMA) }\end{array}$ & $\begin{array}{l}\text { Pembuatan Data } \\
\text { Warehouse } \\
\text { Pembuatan Evaluation } \\
\text { Monitoring } \\
\text { Application (EMA) }\end{array}$ & Service pelaporan kegiatan & $\begin{array}{l}\text { Evaluation Monitoring } \\
\text { Application (EMA) }\end{array}$ \\
\hline
\end{tabular}

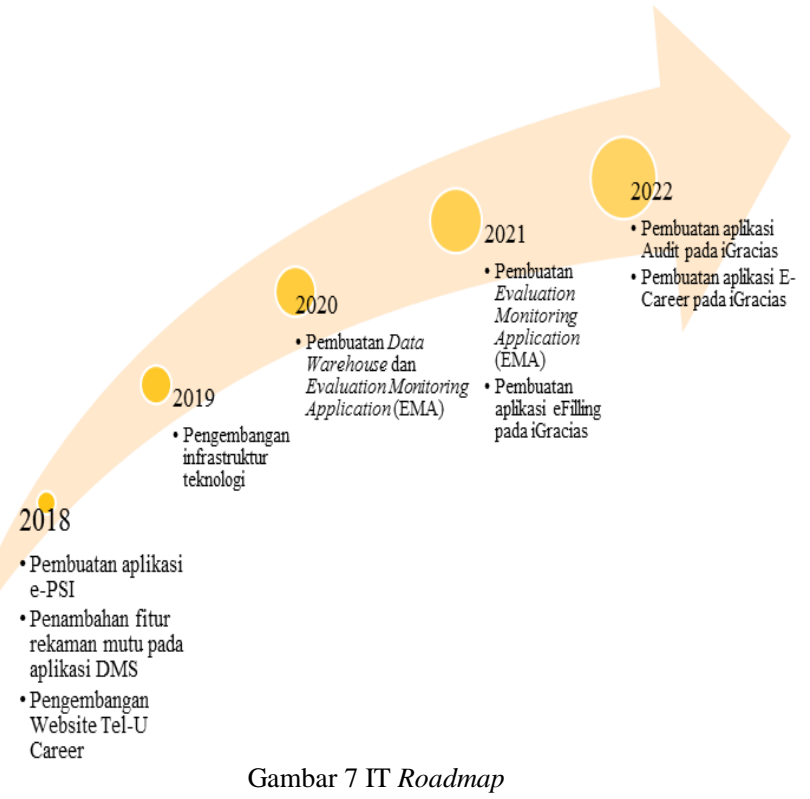

\section{KESIMPULAN}

Penelitian ini dilakukan di Universitas Telkom pada fungsi pengembangan karier, dengan melakukan perancangan enterprise architecture menggunakan TOGAF ADM dari fase preliminary sampai dengan fase migration planning. Berdasarkan hasil perancangan EA pada fungsi pengembangan karir Te-U terdapat beberapa usulan berupa pengembangan website Tel-U Career dan pembuatan aplikasi baru yakni E-Career, eFilling dan Evaluation Monitoring Application (EMA). Untuk aplikasi E-Career dan eFilling diintegrasikan dengan aplikasi utama Tel-U yaitu iGracias, sehingga dengan adanya usulan aplikasi ini dapat mendukung proses bisis pada fungsi pengembangan karier Tel-U untuk saling terintegrasi. Selain itu, pada technology architecture diusulkan adanya pembangunan sistem data warehouse dan business intelligence sehingga diharapkan dapat mempercepat aksesibilitas high level management dalam memonitoring laporan evaluasi, serta penambahan kapasitas pada RAM Server untuk meningkatkan performance aplikasi dan menghindari gangguan pada server. Pada penelitian ini menghasilkan blueprint enterprise architecture dan IT Roadmap di Universitas Telkom pada fungsi pengembangan karier.

TABEL VI

\begin{tabular}{ccc}
\multicolumn{2}{c}{ PRIORITAS PEMBANGUNAN PROYEK PADA FUNGSI PENGEMBANGAN KARIER } \\
\hline No & Solusi & Urutan Prioritas \\
\hline 1 & Pengembangan Infrastruktur Teknologi & 1 \\
2 & $\begin{array}{c}\text { Pembuatan Data Warehouse dan Evaluation } \\
\text { Monitoring Application (EMA) }\end{array}$ & 2 \\
3 & Pengembangan website Tel-U Career & 3 \\
4 & Pembangunan aplikasi eFilling pada iGracias & 4 \\
5 & Pembangunan aplikasi E-Career pada iGracias & 5
\end{tabular}


TABEL VII

EVALUASI PENELITIAN

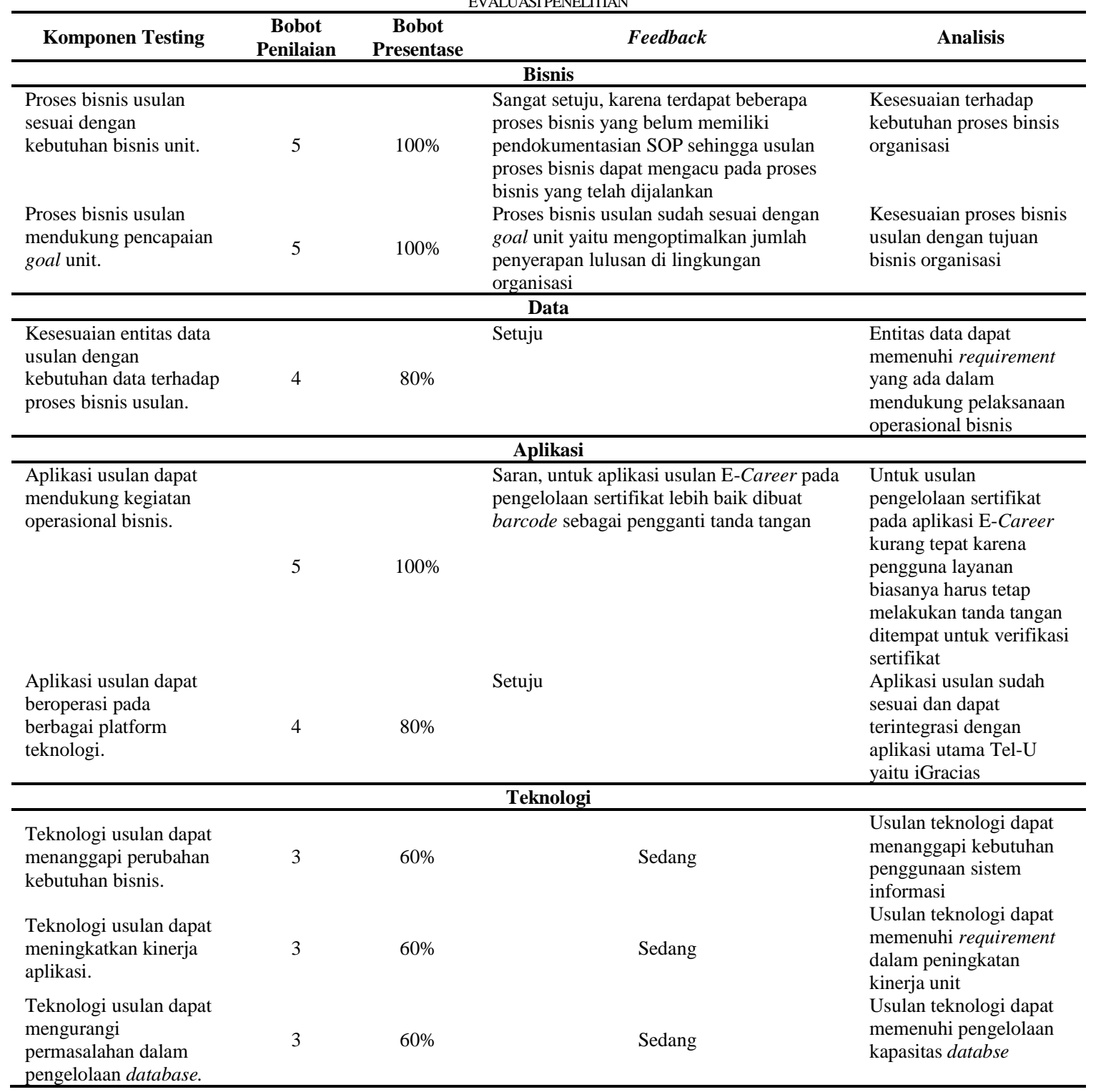

\section{DAFTAR PUSTAKA}

[1] Faradiba, F., Murahartawaty, \& Hanafi, R. (2016). Analisis dan Perancangan Business Architrcture Menggunakan The Open Group Architecture Framework Architecture Development Method (TOGAF ADM) pada PT. Shafco Multi Trading. 4.

[2] INTEN. (2016, November 30). Diambil kembali dari ccs.is.telkomuniversity.ac.id:

http://ccs.is.telkomuniversity.ac.id/sejarah-inten/

[3] Kosasi, S. (2002). Peran Teknologi Informasi Dalam Pengembangan Organisasi. 12.

[4] Utomo, A. P. (2014). Pemodelan Arsitektur Enterprise Sistem Informasi Akademik pada Perguruan Tinggi Menggunakan Enterprise Architecture Planning. Jurnal SIMETRIS, Vol 5 No 1, 8.
[5] Prasetyo, Y. A., Gumilang, S. F., \& Wahyuningtihas, E T. (2016). Perancangan Enterprise Architecture Menggunakan Framework TOGAF ADM Pada Bidang Kearsipan BAPAPSI Kabupaten Bandung. 7.

[6] Profile Tel-U Career. (2016, October 30). Diambil kembali dari career.telkomuniversity.ac.id: https://career.telkomuniversity.ac.id/about-us/

[7] Setiawan, E. B. (2009, Juni 20). Pemilihan EA Framework. Seminar Nasional Aplikasi Teknologu Informasi (SNATI), 6.

[8] The Open Group. (2016, Oktober 29). Diambil kembali dari pubs.opengroup.org: http://pubs.opengroup.org/architecture/togaf9-doc/arch/

[9] Kurniawan, B. (2011). Enterprise Architecture Planning Sistem Informasi pada Perguruan Tinggi Swasra dengan Zachman Framework. Majalah Ilmiah UNIKOM, 9, 12. 
[10] Indriani, R., Murahartawaty, M., \& Hanafi, R. (2016). Analisis dan Perancangan Technology Architecture Menggunakan The Open Group Architecture Framework Architecture Development Method (TOGAF ADM) Pada PT Shafco Multi Trading. JRSI (Jurnal Rekayasa Sistem Dan Industri), 3(01), 1-6. doi:10.25124/jrsi.v3i01.34

[11] Manolita, R., Murahartawaty, M., \& Hanafi, R. (2016). Perancangan Business Architecture Untuk Fungsi Akademik Pada Institut XYZ Menggunakan Framework TOGAF ADM Studi Kasus Sistem Informasi Akademik (SIAKAD). JRSI (Jurnal Rekayasa Sistem Dan Industri), 3(01), 33-39. doi:10.25124/jrsi.v3i01.39 